ECONOMICS

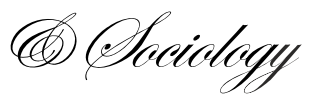

\section{THE MEDIATING ROLE OF LEADERSHIP RELATIONSHIP IN BUILDING ORGANISATIONAL TRUST ON ETHICAL CULTURE OF AN ORGANISATION}

\author{
Aurelija Novelskaitè, \\ Kaunas Faculty of Humanities, \\ Vilnius University, \\ Kaunas, Lithuania, \\ E-mail: \\ aurelija.novelskaite@kbhf.vu.lt \\ Laura Markūnaitè, \\ Kaunas Faculty of Humanities, \\ Vilnius University, \\ Kaunas, Lithuania, \\ E-mail: \\ laura.markunaite@gmail.com
}

Received: April, 2015

1st Revision: June, 2015

Accepted: September, 2015

DOI: $10.14254 / 2071-$

789X.2015/8-3/1

JEL Classification: L33, M14, O30

Keywords: ethical culture of an organisation; leadership relationship; Lithuania; organisational trust; socio-cultural context.

\begin{abstract}
The aim of this paper is to study the effect of leadership relationship on the interplay between ethical culture of an organisation and organisational trust, in particular, its affective and cognitive components in public and private sector organisations in Lithuania. The empirical data were collected with an electronic and paper survey using a standardised questionnaire in 2013-2014 $\left(\mathrm{n}=1070\right.$, seven private organisations, $\mathrm{n}_{\mathrm{pr}}=313$ and one public organisation, $\mathrm{n}_{\mathrm{pub}}=757$ ). A series of linear regression analysis established a mediating effect of leadership relationship on the interplay between ethical culture of an organisation and organisational trust in private organisations, without significant difference on its affective and cognitive components.
\end{abstract}

\title{
Introduction
}

Trust is important for individual well-being (Solomon and Flores, 2001), organisational performance (Connell et al., 2003; Jones and George, 1998; McAllister, 1995; Whitener et al., 1998; Wicks and Berman, 2004; Wicks et al., 1999) and socio-economic development of the country (Fukuyama, 1995; Putnam, 1993; Uslaner, 2002). From an organisational perspective, trust is critical for minimizing uncertainty, risks and operating costs, enhancing employees' commitment and productivity, facilitating organisational learning, knowledge sharing and creation, organisational innovativeness and innovation (Chung and Jackson, 2011; Ellonen et al., 2008; Perry, 2004; Tschannen-Moran, 2001; Zanini, 2007). Trust becomes an acute issue when it is missing. To compensate lack of trust, organisations implement monitoring and control measures, individuals engage in self- 
protective behaviours, get distracted from task performance, which accounts for increased workload and diminished efficiency at both individual and organisational levels (Mayer and Gavin, 2005; Colquitt et al., 2011). At societal level, low trust and consequent uncertainty and risk are handled by developing coping strategies such as bribery, favouritism, excessive litigiousness etc. (Sztompka, 1999). Socialization of individuals in a low-trust societal context affects their attitudes and behaviour in the organisational context, which raise obstacles to organisational development and national competitiveness. Therefore, although in certain cases high trust may account for groupthink and eliminate competent "outsiders" from an organisation (Fukuyama, 1995; Granovetter, 1973), it is generally desirable.

In this paper, we regard organisational trust as a positive attitude held by one organisational member towards the other as competent, honest and benevolent (cf. Mayer et al., 1995) and continuously acting by fair-play rules, ethical norms and common values (Fukuyama, 1995). Such behaviour signals to the trustor that the trustee will not take an advantage of her vulnerability and dependence in a risky situation (Das and Teng, 1998; Lewis and Weigert, 1985; Six, 2007). Abilities and integrity provide rational reasons to trust and account for development of the so-called cognitive trust, and perceived benevolence as well as compliance with the same ethical norms and values constitutes the background for enhancement of emotional trust (Colquitt et al., 2011; McAllister, 1995; McAllister et al., 2006). In this light, organisational trust is an issue in post-soviet context where sociohistorical processes conditioned a rather flexible attitude to norms and standards, lack of integrity, professional negligence among society members, which resulted in low trust (Ees and Bachmann, 2006; Ivanauskas, 2006; Pučètaitė and Lämsä, 2008a; Rees and Miazhevich, 2008; Vasiljevienè and Freitakienè, 2002; Žiliukaité et al., 2006). Therefore, building organisational trust is a practical challenge that calls for theoretically sound and contextsensitive models (Doney et al., 1998; Lämsä and Pučètaite, 2006; Li, 2012; Wicks and Berman, 2004).

However, there is little research from post-soviet context highlighting antecedents of organisational trust. Prior research in this context (Pučètaite et al., 2010a) found organisational trust to depend on human resource management (HRM) practices that are based on the principles of fairness and justice as well as employee participation in decisionmaking and open communication. Another study on the effects of ethics management tools such as ethics codes, ethics training, ethics auditing etc. in Lithuanian organisations (Pučètaitè and Lämsä, 2008b; Pučètaitè et al., 2010a) indicated that the explanatory power of ethics management tools in relation to organisational trust is weak. Besides, post-soviet societies are characterised by a tendency to take documented ethical norms as relativistic conventions (Ryan, 2006; Ungvari-Zrinyi, 2001; Vasiljevienė and Freitakienė, 2002). These effects were identified in private sector organisations only, and public organisations, where ethics management tools were introduced as a requirement for the accession to the European Union or employee participation was promoted by implementation of quality management standards, the situation could be quite different. Therefore, the above mentioned studies concluded that organisational practices and leadership behaviour which show respect and care to employees may be more important to development of organisational trust in such contexts (cf. Brien, 1998; Colquitt et al., 2011), calling for further explorations.

Therefore, in this paper we aim to contribute to the academic discourse on the antecedents of organisational trust by addressing the above mentioned gaps and empirically testing the impact of ethical culture of an organisation and leadership relationship on organisational trust. Although organisational culture and organisational trust are considered intertwined (Brien, 1998; Six, 2007; Vasiljevienè, 2000), there are few studies which explore the effects of the ethical dimension of organisational culture on the cognitive and affective components of organisational trust. In addition, we are interested in the effect of leadership, 
which we view as a dyadic relationship between leader and followers, on the interplay between these two phenomena. Prior studies provide evidence that leadership relationship enhances the effect of leader's traits such as competence and ability, based on which followers' trust is built (Hernandez et al., 2014) and it can serve as an organisational practice that strengthens the role of normative rules and procedures on trust (Six, 2007). However, empirical evidence about the role of leadership relationship in the interplay between ethical culture of an organisation and organisational trust is scarce. Therefore, with this paper we try to address this gap in the related literature.

Our paper is structured into three parts. The first one introduces the key concepts and reasons the interrelations between them. It is followed by the research methodology and empirical findings from a quantitative study in private and public organisations in Lithuania. Finally, the findings are discussed, considering managerial implications to public and private sector organisations operating in a socio-cultural context of low trust.

\section{Conceptual framework and hypotheses}

Organisational trust has been referred to as the glue of societies (Fukuyama, 1995), basis for quality of interrelations (Lewicki and Bunker, 1996) and a source of competitive advantage in knowledge economy (Barney and Hansen, 1994; Zanini, 2007). In this paper, we focus on organisational trust from an interpersonal, co-workers' dimension as it is less explored compared to the studies of trust from the viewpoint of vertical relationships (i.e. supervisor-employee) in organisations (Tan and Lim, 2009). Moreover, based on prior research on organisational trust (Jones and George, 1998; Lewis and Weigert, 1985; McAllister, 1995; Whitener et al., 1998; Wicks et al., 1999; Young and Daniel, 2003), we distinguish between two types of the studied phenomenon, i.e. cognition- and affect-based organisational trust. They differ in the motives for the willingness to trust the other party. The cognitive component of organisational trust rests on evaluative predictions and calculations, such as a certain extent of experience and knowledge about the other actor, and the probability of the reciprocal behaviour (Tyler and Kramer, 1996). This kind of organisational trust implies that one party trusts the other because both have acted in a trustworthy, competent way in the past and can be expected to do so in the future (Gulati and Sytch, 2008; Ristig, 2009). In other words, cognitive trust involves a rational appraisal which helps the parties not to trust unwisely. Yet, cognitive trust is said to work best only in short-term and casual affairs. To achieve sustainable organisational development with a long-term orientation, affect-based trust is needed. The affective component is related to the emotional side of trust. This form of trust is often self-evident and tacit and results from an interaction over a long(er) period of time as relationships become mature (Gulati and Sytch, 2008; Thomson et al., 2009). It is built on values, standards, principles and involves a mutual expectation of fair and honest behaviour (Gulati and Sytch, 2008; Lämsä and Pučetaitè, 2006; cf. Barney and Hansen, 1994).

Organisational trust depends on the relationship between the parties and opportunities they have to learn about each other's capability to perform well in a particular social role or accomplish certain functional tasks. Therefore, the character of trust in the same person may vary (cf. Lewicki et al., 1998). For example, we trust a university colleague to do statistical analysis for a research article because she is a knowledgeable mathematician, but we may not trust her as an interviewer because we know her poor social competences. However, this divergence does not preclude us from trusting her generally if she continuously follows the same ethical principles and values, in particular, if they are common with ours. Shared ethical values are important for developing affective trust as they resonate with the feelings of justice and fairness, empathy and care and incite willingness to reciprocate the other party. This 
mechanism accounts for development of mature and strong ties which contribute to positive organisational outcomes but may also have detrimental effects such as overlooking rule breaking or even lying (Grover, 2010).

The other concept used in this study, ethical culture of an organisation rests on the Corporate Ethical Virtues (CEV) model, a multidimensional construct proposed by Kaptein (2008). The model departs from a virtue-based theory of business ethics (Solomon, 2004) that has its roots in Aristotle's virtue ethics and considers virtues as indicators of an ethical character. According to Kaptein (2008), the ethicality or virtuousness of an organisation can be determined by the extent to which organisational culture stimulates the organisation to act ethically and prevents them from unethical behaviour. The CEV model consists of eight virtues, i.e. clarity, congruency of supervisor, congruency of management, feasibility, supportability, transparency, discussability and sanctionability. Clarity refers to explicit expectations of an organisation to employees that they act ethically. This virtue in practice is embodied in ethics codes or any other institutionalised forms of values. Congruency of supervisors and management refer to integrity and the role models that supervisors and management show to the employees. These three virtues constitute the basis for organisation's self-regulation (Kaptein, 2008). Feasibility is related to resources allocated by an organisation so that employees would be able to follow the normative expectations. Supportability denotes organisational support and encouragement to follow the norms. A virtuous organisation integrates ethical principles that are declared in ethics codes or any other normative documents into its operational systems. These two virtues are self-providing as they enable employees to comply with ethical principles and values. Transparency is a degree to which consequences of employees' ethical or unethical behaviour are perceived by employees themselves and their colleagues. Ethical organisations are open, do not tolerate breaches of ethical principles and ensure proper internal communication. Discussability concerns employees' opportunities to be open and sincere when facing ethical issues and have a possibility to discuss them. This virtue rests on ethics management tools such as ethics training and ethics office and may involve internal whistle-blowing mechanisms such as an ethics hotline. The last virtue, sanctionability relates to the degree employees perceive that unethical behaviour is punished or rewarded in the organisation. Practising this virtue presupposes ethics auditing in the organisation and self-corrective actions striving for continuous improvement and prevention of ethical misdeeds.

Finally, our definition of the leadership phenomenon rests upon a leadership relationship theory, namely, leader and member exchange theory (hereafter LMX, Graen and Uhl-Bien, 1995; Uhl-Bien, 2006). The theory focuses on the two-way influence between leader and followers rather than just on leader's or followers' influence on the other party. It departs from theories of social interrelations (e.g. social exchange theory - Blau, 1964) and holds that interrelations between leader and followers may differ depending on the quality of the relationship. The LMX theory distinguishes relationships between leader and the so-called "in-group" and "out-group" members which are termed, respectively, high and low LMX (Anand et al., 2011). High LMX or in-group relationships can be described by loyalty, respect, high trust and liking between leader and followers based on the performance of a social role while low LMX or out-group relationships can be characterized by following employment contract, managing by autocratic methods and low trust between the parties (Dansereau et al., 1975). To some extent, high LMX has risks of turning into nepotistic relationships, in particular in post-soviet societies where personal relationships or rudiments of blat, which has cultural analogies with quanxi (Rehn and Taalas, 2004; Ledeneva, 2008; cf. Nie and Lämsä, 2015) still make impact on business and professional relationships. However, as argued by Graen and Uhl-Bien (1995), although LMX views leader and followers' relationships personalised, the relationship is limited to the working context and does not 
include affective feelings which can be found in personal relationships; rather, loyalty, liking and respect in LMX rest on perceived competence and professionalism when performing one's social role played in the organisational context. Hence, LMX inherits characteristics of 'good leadership' which balances positive performance results (effectiveness), ethical ways of achieving them and personal characteristics which work to the benefit of all parties involved in a particular context (Ciulla and Forsyth, 2011; Hogan and Kaiser, 2005).

\subsection{Ethical culture of an organisation and organisational trust}

The impact of ethical culture of an organisation on organisational trust can be explained by person-organisation fit (Chatman, 1989) which is defined as congruence between individual and organisational values. Ethical values are of particular importance for this congruence. Prior studies have found that shared ethical values have a positive effect on person-organisation fit (Andrews et al., 2011). Ethical virtues and organisational practices which integrate them send signals to the trust parties to open up for relationship building and social exchanges, which presupposes the need for trust. As trust emerges in the presence of integrity, benevolence and openness, ethical culture of an organisation can serve as the basis for development of organisational trust.

Another theory that is helpful in explaining development of organisational trust by ethical culture of an organisation is relational signalling theory. It holds that human behaviour is goal-directed (i.e. framed) and context-dependent (Lindenberg, 1998; Six and Sorge, 2008). Organisational systems give a frame based on which employees make decisions and take actions. From a relational signalling perspective, following ethical norms and principles of an organisation is regarded as exchange of relational signals that allow individuals to make a decision to rely on each other and engage in self-regulation (Mühlau and Lindenberg, 2003). Ethical virtues which constitute ethical culture of an organisation such as feasibility, which empowers employees to follow ethical values of the organisation, or discussability, which gives a chance to employees to speak openly about moral concerns to the colleagues and management, or sanctionability, which ensures that people who compromise ethical values have no future in the organisation and those who follow ethical values have opportunities to be adequately rewarded, send a message to employees that they are respected and fairly treated. These signals ensure reciprocity which is needed for trust building and cooperation.

Such an organisational context builds a sense of inclusion where human dignity is secured. Positive feelings such as being respected and valued may account for stronger identification with the team (Ellemers et al., 2013) and organisational goals (cf. Huhtala et al., 2013), accounting for understanding of an organisation as benevolent and trustworthy and development of organisational trust. Working for an organisation with the same values may further increase an individual's identification with a group or an organisation and develop affectual bonds with its members (Williams, 2001). For example, Ruiz-Palomino et al. (2013) found that ethical culture of an organisation and person-organisation fit account for affective commitment and willingness to recommend the organisation to others. These studies indicate that congruence of ethical values incite positive emotions and can account for an individual's attitude to co-employees and the organisation as benevolent and trustworthy. Even though people may not interact directly with each other, experience with organisational systems operating by ethical principles and norms may be sufficient to build organisational trust.

For example, ethical values integrated in human resource management systems will guarantee that if any of the organisation's members violates its principles and rules, she will lose membership in the organisation and consequently all the privileges associated with it. In this way, an organisation sends a signal to individuals that there is a reason to follow the 
values and enjoy the benefits of trust and motivates employees to justify expectations for proper behaviour, which eventually builds organisational trust, in particular its cognitive component. Such regularities are typical of professions as institutions (Brien, 1998). Historically, professions tried to purge themselves from technically and ethically incompetent members to secure public trust and autonomy which was granted to them by a society in exchange for exclusive knowledge owned by a profession.

Analogous situations can be characteristic of organisations in which ethical values are integrated into their management systems (cf. Six, 2007). In this respect, organisation's ethics code may be signalling even to new employees that the organisation may be worth trusting and induce trust. The studies by Pučètaite et al. (2010a; 2010b) demonstrate that employees of multinational organisations which are reputable as employers and have corporate social responsibility programmes and/or ethics codes, developed affective trust first and later rationalised it. However, in public organisations, ethical culture of an organisation could induce cognitive trust first as these organisations are much more bureaucratic compared to private organisations; their activities and management practices are much more standardized and therefore ethical culture of an organisation may be perceived as a regulatory mechanism, which appeals to rational judgement rather than emotions.

Hypothesis 1: Ethical culture of an organisation has a positive effect on organisational trust.

Hypothesis la: In private organisations, ethical culture of an organisation has a stronger effect on affective trust than on cognitive trust.

Hypothesis 1b: In public organisations, ethical culture of an organisation has a stronger effect on cognitive trust than on affective trust.

\subsection{The mediating role of leadership relationship}

Employees' perceptions of the quality of leader-follower relationships determine how employees perceive the whole organisation (cf. Hernandez et al., 2014, p. 1873). The LMX quality strengthens the effect of CEV that signals to employees that they are respected and cared about. If organisation's management and direct supervisors emphasize importance of organisational values and follow them in their decisions and behaviours, not only they as persons are perceived as fair and acting with integrity, but also leadership as an organisational practice serves as evidence of organisational reliability to employees.

LMX is characterised by a certain degree of reciprocity, loyalty, respect and interpersonal trust which stems from the excellence in accomplishing one's social role in the organisation. This characteristic is important for developing organisational trust in a postsoviet context. During soviet years, a hierarchical structure of organisations favoured abuse of power, opportunism, uncritical support to the ones in higher positions, mutual adversity and initial distrust that presupposed resulted low trust and a need for strict control (Pučetaitè and Lämsä, 2008a; Pučètaitè and Novelskaitè, 2014). As LMX presupposes mutual obligations, reciprocal communication, fairness and justice, such leadership practices experienced in the ethical culture of an organisation, may have a resocializing effect and induce organisational trust. Belonging to an organisation where ethically sound organisational practices are complemented by leadership relationship and experienced fairness may enhance a sense of membership in an organisation, construct a moral identity and induce positive affect related to the organisation and its members, which can predict organisational trust (Cropanzano and Stein, 2009; Lerner, 2003; Williams, 2001). Based on that, we can assume that LMX will strengthen the impact of CEV on affective trust particularly. LMX embeds fairness and respect which touch a human need for experiencing positive emotions such as recognition and self-esteem. Moreover, care, empathy, sensitivity, respect to and understanding of each 
other's needs, interests and feelings strengthen emotional bonds and motivation to reciprocate and act in benevolence to every member of the organisation, assuming that they are following the same ethical virtues in their decisions and actions.

Hypothesis 2: Leadership relationship will mediate the relationship between ethical culture of an organisation and organisational trust.

Hypothesis 2a: The mediating effect of leadership relationship on the interplay between ethical culture of an organisation and affective trust is stronger than the one between ethical culture of an organisation and cognitive trust.

\section{Research setting, methods and data}

The empirical data $(n=1070)$ were collected by a standardized questionnaire from public and private organisations in Lithuania in 2013-2014. One of them was a large public organisation $(\mathrm{n}=757)$, the rest of them were small and medium-size private organisations operating in telecommunication and smart technologies, manufacturing, retail, construction and recycling sectors $(n=313)$. The response rate from the public organisation was above $50 \%$, while the response rate from the private ones ranged from 20 to $35 \%$.

The samples are dominated by women, $80 \%$ in the public sector company and $67 \%$ in the private one. Most of the respondents in the public sector organisation were specialists (over $80 \%$ ). In the private organisations, just $46 \%$ of the respondents marked their position: $10 \%$ of the respondents represented management, $16 \%$ administration, and $20 \%$ specialists. More than half of the respondents in both sectors had higher education: $98 \%$ in the public organisation and $52 \%$ in the private organisations. The mean of employment experience was 14 years for the public organisation's employees (Std. dev. $=8)$ and 6 years for employees of the private organisations (Std. dev. $=7$ ). The largest age group $(45 \%)$ in the public organisation was the one above 50 years followed by $29 \%$ of the respondents in the age group between 41 to 50 years. As age was measured in two ways, i.e. by indicating an age range in five private companies and by indicating their age in the other two $(n=60)$, in the case of age ranges, the largest age group (34\%) was the one between 21 to 30 years, and the other age groups were rather evenly distributed, ranging from 12 to $16 \%$. In the case of the exact age $(\mathrm{n}=60)$, the mean was 36 years $($ Std. dev. $=10)$.

The questionnaire was distributed as an e-survey in most companies, except one where an e-survey was complemented by a paper version. The procedure for distributing the e-survey was the same: the top management was contacted and after the permission was granted, a link to the communication department was sent to be further distributed to the employees. In the company where paper versions of the questionnaire were distributed the an administrator was responsible for distributing and collecting the questionnaires from the employees.

The questionnaire consisted of four thematic scales. Organisational trust was measured by McAllister's (1995) 11-item questionnaire with a 7-item grading scale (1 denoting "totally disagree" and 7 "totally agree"); 5 statements were used to measure affective trust, and 6 cognitive trust. Ethical culture of an organisation was measured by the CEV questionnaire that was originally created and validated by Kaptein (2008). It consists of 58 statements encompassing 8 virtues, i.e. clarity, congruency of supervisor, congruency of management, feasibility, supportability, transparency, discussability and sanctionability, evaluated by a 6item scale (1 denoting "totally disagree" and 6 "totally agree"). Quality of leadership relationship was measured by an LMX questionnaire (Graen and Uhl-Bien, 1995) which consists of 7 statements measured with a 5-item Likert scale (1 denoting "totally disagree" and 5 "totally agree"). Some items originally were reverse coded and were adequately transformed for analysis. The fourth block of questions included the background 
characteristics of the respondents, i.e. gender, education, position in the organisation, employment years in the organisation.

Statistical analysis of the data was accomplished using SPSS for Windows 22.0 software. The data were analysed in two sub-samples (i.e. public and private organisations) and three groups of variables: a group consisting of two variables for affective and cognitive trust, eight variables measuring ethical culture of an organisation and one group of LMX. Cronbach's alphas were sufficient (the lowest 0.85 ) for all the variable sets (see Table 1).

The data were analysed in several steps. First, for an initial exploratory comparison of the public and private organisations samples, descriptive characteristics were calculated (i.e. min and max values, mean, std. deviations). Further, statistical significance of differences between the average evaluations was tested employing nonparametric Wilcoxon Signed Ranks, Mann-Whitney U \& Wilcoxon W tests, and Kolmogorov-Smirnov tests. Second, ordinary partial correlations (Spearman's rho coefficients) between different types of CEV and organisational trust were calculated for both samples. Third, the effects of CEV and LMX on the two types of organisational trust were tested with a series of linear regressions (stepwise method). Based on that, different interpretative models were developed with a range from 1 to 4 of which the one with the strongest explanatory power was selected for interpretation and discussion.

\section{Findings}

As indicated in Table 1, average evaluations of LMX are similar in both private and public organisations, being almost as high as 4 points (Std. dev. $=0,8-0,9$ ). This evaluation (4 out of 5 points) characterises leadership relationships as the ones of high quality. However, the level of organisational trust is slightly higher among the respondents working in the private organisations than in the public one; this difference is statistically significant. Additionally, it is worth drawing attention to the level of affective trust, which is statistically significantly higher among the respondents from the private organisations, meanwhile the level of cognitive trust is higher among the respondents from the public organisation.

Table 1. Descriptive statistics

\begin{tabular}{lcccccc}
\cline { 2 - 7 } & \multicolumn{3}{c}{ Private org. } & \multicolumn{3}{c}{ Public org. } \\
\hline & $\mathrm{N}$ & Mean & Std. Dev. & $\mathrm{N}$ & Mean & Std. Dev. \\
\hline $\begin{array}{l}\text { Leader-member exchange } \\
\text { (total) }\end{array}$ & 283 & 3,9 &, 846 & 465 & 3,9 &, 943 \\
\hline Organisational trust (total) & 271 & 5,1 & 1,135 & 509 & 4,9 & 1,106 \\
\hline Affective trust & 291 & 5,0 & 1,333 & 643 & 4,6 & 1,434 \\
\hline Cognitive trust & 275 & 5,1 & 1,148 & 545 & 5,2 & 1,102 \\
\hline CEV (total) & 254 & 4,7 &, 808 & 248 & 4,6 &, 836 \\
\hline Clarity & 284 & 4,9 &, 904 & 510 & 5,2 &, 839 \\
\hline Congruency of supervisor & 296 & 4,9 & 1,157 & 620 & 5,2 & 1,091 \\
\hline Congruency of management & 299 & 4,8 & 1,144 & 634 & 5,0 & 1,124 \\
\hline Feasibility & 306 & 4,7 & 1,210 & 695 & 4,7 & 1,191 \\
\hline Supportability & 300 & 4,4 & 1,197 & 603 & 4,7 & 1,055 \\
\hline Transparency & 278 & 4,4 & 1,079 & 341 & 4,3 &, 957 \\
\hline Discussability & 284 & 4,6 & 1,005 & 432 & 4,6 & 1,055 \\
\hline Sanctionability & 279 & 4,6 & 1,004 & 387 & 4,4 & 1,078 \\
\hline
\end{tabular}

Source: own calculation. 
At this point, a brief comment on the difference in the number of responses to particular variables in the samples should be made. A different number of responses to certain questions as indicated by descriptive findings in Table 1 imply that the respondents either avoided a direct answer or simply did not have enough knowledge of or had not reflected certain organisational practices related to the studied phenomena. Considering reluctance of the respondents from private companies to fill in all the information in the socio-demographic block of questions, we may just assume that in some private companies there is uncertainty about the consequences of assessing leader's behaviour or value-laden organisational practices, which implies a lack of trust in organisation or its management.

Moreover, the results of nonparametric Wilcoxon Signed Ranks Test show that there is no statistically significant difference between average evaluations of affective and cognitive trust in the private organisations (see Table 2). However, they statistically significantly differ, denoting lower levels of affective trust in the public organisation.

In general, an average evaluation of CEV is almost the same in the private and public organisations. However, in the public organisation, the ethical virtues of clarity and congruency of supervisor received the highest average evaluations (i.e. mean $=4,9$ ) which statistically significantly differ compared to evaluations of all the other virtues. The only exception is feasibility: a statistically significant difference is not found because of a higher standard deviation. On the opposite end of the list of ethical virtues, supportability and transparency received the lowest average evaluations (i.e. mean $=4,4$ ) and they are statistically significantly different from others. The virtues of discussability and sanctionability with average evaluations of 4,6 points appear in the middle, being statistically significantly different from other average evaluations.

Table 2. Test statistics private vs. public organisations

\begin{tabular}{lcccc}
\hline & $* Z$ & Asymp. Sig. (2-tailed) & $* * Z$ & Asymp. Sig. (2-tailed) \\
\hline $\begin{array}{l}\text { Leader-member exchange } \\
\text { (total) }\end{array}$ &,- 360 &, 719 &, 894 &, 401 \\
\hline $\begin{array}{l}\text { Organisational trust } \\
\text { (total) }\end{array}$ & $-2,273$ &, 023 & 1,458 &, 028 \\
\hline Affective trust & $-4,022$ &, 000 & 2,291 &, 000 \\
\hline Cognitive trust &,- 305 &, 760 &, 640 &, 807 \\
\hline $\mathbf{C E V}$ (total) & $-1,852$ &, 064 & 1,722 &, 005 \\
\hline Clarity & $-5,236$ &, 000 & 2,543 &, 000 \\
\hline Congruency of supervisor & $-5,049$ &, 000 & 3,244 &, 000 \\
\hline Congruency of management & $-4,488$ &, 000 & 2,864 &, 000 \\
\hline Feasibility &,- 784 &, 433 & 1,098 &, 179 \\
\hline Supportability & $-3,533$ &, 000 & 1,589 &, 013 \\
\hline Transparency & $-2,375$ &, 018 & 1,691 &, 007 \\
\hline Discussability &,- 931 &, 352 & 1,340 &, 055 \\
\hline Sanctionability & $-1,822$ &, 068 & 1,408 &, 038 \\
* results of Mann-Whitney U and Wilcoxon W tests. & & & \\
** results of Kolmogorov-Smirnov test. & & & \\
\hline
\end{tabular}

Source: own calculation.

Similarly, clarity and congruency of supervisor received the highest evaluations (mean $=5,2$ ) among the respondents working in the public organisation. However, transparency and sanctionability received the lowest evaluations (means $=4,3$ and 4,2 respectively) in this organisation. The virtues of feasibility, supportability and discussability appear in the middle of the highest and the lowest evaluations. 
Comparison of the average evaluations of ethical virtues in the private and public organisations using nonparametric Mann-Whitney $U$ and Wilcoxon $W$ as well as Kolmogorov-Smirnov tests shows that evaluations of several virtues are equal in the 2 subsamples. These are feasibility, discussability and sanctionability. The other virtues received statistically significantly higher evaluations in the public organisation.

The results of correlation analysis between CEV and organisational trust demonstrate that all variables (including distinct constituents of the separate variables) are rather strongly (or at least statistically significantly) interconnected; all interrelations are positive (see Annexes $A-1$ and $A-2)$. Most of the correlations are stronger in the data from the public organisation than from the private ones. Such a result reflects high reliability of the measurement instrument and implies that it is more suitable for measuring the phenomena in the public sector or in large organisations where institutionalisation of norms is inevitable to ensure effective management. On the other hand, these findings may reflect the nature of the samples: the sample from the public organisation is homogeneous and depicts culture of one organisation (not considering variance of attitudes of individual respondents); meanwhile the sample of the private organisations is heterogeneous and, in addition to variety of individual attitudes, reflects features of cultures of different organisations.

Results of correlation analysis between CEV and organisational trust with LMX as a control variable (see Annexes $B-1$ and $B-2$ ), indicate that organisational trust statistically significantly correlates with both CEV and LMX. The internal correlation of components of the organisational trust is rather strong in both types of organisations.

The regression analysis of organisational trust on CEV demonstrates that ethical culture makes statistically significant impact on organisational trust, yet its impact on the affective and cognitive components in both types of organisations is similar (see Table 3). The coefficient $\mathrm{R}^{2}$ Adj for the impact of CEV on organisational trust, affective trust and cognitive trust in the private organisations is fluctuating at 0,3 with respective Betas $=0,5-0,6$. In the public organisation, the effect is similar to the one in the private organisations, just the explanatory power of CEV on cognitive trust is just 5\% stronger than the one of $\mathrm{CEV}$ on affective trust $\left(\mathrm{R}_{\text {Adj }}^{2}=0,22\right.$ vs. $\mathrm{R}_{\text {Adj }}^{2}=0,27$ respectively $)$. These results confirm Hypotheses $1,1 \mathrm{a}$ and $1 \mathrm{~b}$.

Table 3. Regression of organisational trust on CEV with LMX as a mediator

\begin{tabular}{|c|c|c|c|c|c|c|c|c|}
\hline \multirow{3}{*}{\multicolumn{2}{|c|}{$\begin{array}{l}\text { Regression } \\
\text { model }\end{array}$}} & \multirow{3}{*}{$\begin{array}{l}\text { Independent } \\
\text { variable(s) }\end{array}$} & \multicolumn{6}{|c|}{ Dependent variable(s) } \\
\hline & & & \multicolumn{2}{|c|}{$\begin{array}{l}\text { Organisational trust } \\
\text { (total) }\end{array}$} & \multicolumn{2}{|c|}{ Affective trust } & \multicolumn{2}{|c|}{ Cognitive trust } \\
\hline & & & $\mathrm{R}_{\text {Adj }}^{2}$ & $\begin{array}{c}\text { Stand. } \\
\text { Coeff. Beta }\end{array}$ & $\mathrm{R}_{\text {Adj }}^{2}$ & $\begin{array}{c}\text { Stand. } \\
\text { Coeff. Beta }\end{array}$ & $\mathrm{R}_{\text {Adj }}^{2}$ & $\begin{array}{c}\text { Stand. } \\
\text { Coeff. Beta }\end{array}$ \\
\hline \multirow[b]{2}{*}{$\begin{array}{l}\text { Private } \\
\text { org. }\end{array}$} & 1 & CEV (total) & 0,316 & 0,565 & & 0,527 & & 0,515 \\
\hline & 2 & $\begin{array}{l}\text { CEV (total) } \\
\text { LMX (total) }\end{array}$ & 0,371 & $\begin{array}{l}0,377 \\
0,314\end{array}$ & 0,315 & $\begin{array}{l}0,359 \\
0,282\end{array}$ & 0,302 & $\begin{array}{l}0,372 \\
0,250\end{array}$ \\
\hline \multirow{2}{*}{$\begin{array}{l}\text { Public } \\
\text { org. }\end{array}$} & 1 & CEV (total) & 0,305 & 0,556 & 0,224 & 0,477 & 0,266 & 0,519 \\
\hline & 2 & $\begin{array}{l}\text { CEV (total) } \\
\text { LMX (total) }\end{array}$ & 0,327 & $\begin{array}{c}0,484 \\
0,124 *\end{array}$ & 0,262 & $\begin{array}{c}0,400 \\
0,153 *\end{array}$ & 0,269 & $\begin{array}{c}0,493 \\
0,045^{*}\end{array}$ \\
\hline
\end{tabular}

* statistically insignificant.

Source: own calculation.

Furthermore, statistical theory says that "a variable that influences the relation between two other variables" is a moderator (i.e. a moderating variable) (Vogt, 2005, p. 195); the variable which "transmits" the effects of another variable is a mediator (i.e. a mediating variable) (ibid, p. 190). Hence, analysis of correlation between organisational trust and CEV and analysis of a partial correlation between the variables with LMX as a control variable 
suggest that the latter has a moderating effect on the interrelation (see the Annexes). That is, LMX decreases the strength of linear correlation between organisational trust and CEV in all cases in both the public and private organisations.

More specifically, LMX has a rather weak moderating effect on the interrelations between cognitive and affective trust in both types of the organisations. Meanwhile in the case of the interplay between different ethical virtues LMX has both moderating and mediating effects in the private organisations. That is, in most cases, a moderating effect of LMX appears as decreasing strength of correlations between different virtues, but it also increases the strength of the correlations and performs the role of a mediator in the interrelations between clarity and congruency of management; supportability and congruency of supervisor; and sanctionability and discussability.

The mediating effect of LMX on the interplay between CEV and organisational trust is supported by the results of regression analysis of the data from the private organisations only (see Table 3): the presence of LMX in the regression equation decreases the effect of CEV but increases the general explanatory power of the model. However, in the case of the public organisation, presence of LMX in the regression equation is statistically insignificant. Comparison of its mediating effect on the interplay between CEV and the affective and cognitive components of trust in the sub-sample of private organisations shows that its power is just slightly (i.e. 5\%) stronger on affective rather than cognitive trust. Therefore, we conclude that the findings confirm Hypotheses 2 and 2a.

Deeper explorations of the effects of LMX on the interrelation between CEV and organisational trust show that LMX performs a mediating role when separate ethical virtues are analysed as determinants of organisational trust and its affective and cognitive components (see Table 4). Incorporation of LMX in the model increases its explanatory power in both types of organisations. However, it has no statistically significant effect in the model explaining the effect in the public organisation.

Table 4. Regression of organisational trust on ethical virtues with LMX as a mediator

\begin{tabular}{|c|c|c|c|c|c|c|c|c|}
\hline \multirow{3}{*}{\multicolumn{2}{|c|}{$\begin{array}{c}\text { Regression } \\
\text { model }\end{array}$}} & \multirow{3}{*}{$\begin{array}{l}\text { Independent } \\
\text { variable(s) }\end{array}$} & \multicolumn{6}{|c|}{ Dependent variable(s) } \\
\hline & & & \multicolumn{2}{|c|}{$\begin{array}{l}\text { Organisational trust } \\
\text { (total) }\end{array}$} & \multicolumn{2}{|c|}{ Affective trust } & \multicolumn{2}{|c|}{ Cognitive trust } \\
\hline & & & $\mathrm{R}_{\text {Adj }}^{2}$ & $\begin{array}{c}\text { Stand. } \\
\text { Coeff. Beta }\end{array}$ & $\mathrm{R}_{\text {Adj }}^{2}$ & $\begin{array}{c}\text { Stand. } \\
\text { Coeff. Beta } \\
\end{array}$ & $\mathrm{R}_{\text {Adj }}^{2}$ & $\begin{array}{c}\text { Stand. } \\
\text { Coeff. Beta }\end{array}$ \\
\hline \multirow{8}{*}{$\begin{array}{l}\text { Private } \\
\text { org. }\end{array}$} & 1 & Clarity & \multirow{4}{*}{0,357} & 0,341 & \multirow{4}{*}{0,301} & 0,368 & \multirow{4}{*}{0,313} & 0,242 \\
\hline & & $\begin{array}{l}\text { Congruency of } \\
\text { management }\end{array}$ & & 0,241 & & & & 0,292 \\
\hline & & Feasibility & & 0,175 & & & & 0,205 \\
\hline & & Discussability & & & & 0,234 & & \\
\hline & \multirow[t]{4}{*}{2} & LMX & \multirow{4}{*}{0,412} & 0,304 & \multirow{4}{*}{0,330} & 0,303 & \multirow{4}{*}{0,357} & 0,234 \\
\hline & & Clarity & & 0,227 & & 0,369 & & 0,159 \\
\hline & & $\begin{array}{l}\text { Congruency of } \\
\text { management }\end{array}$ & & 0,194 & & & & 0,261 \\
\hline & & Feasibility & & 0,140 & & & & 0,178 \\
\hline \multirow{6}{*}{$\begin{array}{l}\text { Public } \\
\text { org. }\end{array}$} & \multirow[t]{3}{*}{1} & Supportability & \multirow[t]{3}{*}{0,360} & 0,423 & 0,259 & 0,333 & \multirow[t]{3}{*}{0,327} & \multirow[t]{3}{*}{0,574} \\
\hline & & Feasibility & & 0,125 & & & & \\
\hline & & Discussability & & 0,166 & & 0,216 & & \\
\hline & \multirow[t]{3}{*}{2} & Supportability & 0,401 & 0,567 & 0,324 & 0,422 & \multirow[t]{3}{*}{0,348} & \multirow[t]{3}{*}{0,592} \\
\hline & & Feasibility & & 0,164 & & 0,130 & & \\
\hline & & LMX & & $*$ & & 0,155 & & \\
\hline
\end{tabular}

*LMX was excluded from the model as statistically insignificant.

Source: own calculation. 
As demonstrated by the results, LMX has a rather tenuous effect on organisational trust and its affective and cognitive components in the public organisation. It makes effect on affective trust, however, the effect is weak and identified just in the context which is characterised by colleagues' support to practising ethical virtues and organisational provision of resources to living ethical virtues in the organisational setting. In all the cases where organisational trust is a dependent variable, supportability is the key determinant. In the private organisations, LMX plays a statistically important role in determining both types of trust. Affective trust is advanced through practising the virtue of clarity, which also determines overall organisational trust. In the case of cognitive trust it is feasibility or provision of resources for practicing organisational virtues and the role model demonstrated by managers as indicated by the virtue of congruency of management that make impact.

\section{Discussion and conclusions}

In this paper we took a perspective to trust as a contextual phenomenon and attempted to make a contribution to the academic discourse on how organisational trust can be developed under the impact of ethical culture of an organisation and leadership relationship. Our findings confirm that ethical culture of an organisation can advance organisational trust, and leadership relationship has a mediating effect on this relationship, however, just in private organisations. The explanation for these findings could be high standardisation and bureaucratisation of public sector organisations and still prevailing hierarchical structures which undermine the possibilities of leaders and followers to engage in caring, loyal and sensitive relationships. In these structures, leaders may be appointed on political grounds and changing with every election, therefore, relationships may be kept impartial and formal, following the duties of the employment contract. In private sector organisations, (emotional) investments into leadership relationship may be much more typical and therefore leadermember interaction may exert much stronger influence.

On the other hand, an organisation's size could lend an explanation to the findings. The public organisation in our study was large while the private organisations were small and medium size. Usually interpersonal relationships are closer in small groups, and relationship dynamic is much stronger there. Our explanation is also supported by the study findings: the virtue of discussability became insignificant in the explanatory model of the effect of ethical virtues on organisational trust once LMX was added. It suggests that quality of leadership relationship may substitute organisational systems for voicing ethical issues. However, this is more possible in smaller collectives meanwhile in large bureaucratic organisations systems which annihilate any possibility of subjectivity are important.

The findings also highlight ethical virtues and organisational practices related to ethics management which advance organisational trust. The established effect of clarity on organisational trust and its affective and cognitive components in private sector organisations contributes to the academic discourse on positive effects of ethics codes and their effectiveness generally (Kaptein and Schwartz, 2008). The findings also pinpoint importance of management's integrity and empowerment of employees by providing resources to comply with ethical values for development of organisational trust. These findings are in line with Mayer's et al. (1995) research on competence, benevolence and integrity as the antecedents of trust and lend support to Six's (2007) propositions about the necessity to ensure normative framework and support it with organisational practices if organisational trust is aimed at from a relational signalling perspective. The impact of the discussability virtue on building affective trust in both private and public organisations indicates the necessity of open dialogue in which parties may become "moral acquaintances" (Vasiljevienè, 2004). Considering ethical virtues in public sector, supportability is worth mentioning as it helps to 
build organisational trust and affective and, in particular, cognitive components. This is an interesting finding considering that neither management's integrity nor leadership relationship plays a role in forming the parties' attitudes to each other as trustworthy. It indicates a focus on an institutional rather than an individual perspective when building interpersonal trust between employees, and emotions play a minor role.

Therefore, considering the findings from the private sector, conceptual implications of our study consist in highlighting the role of interpersonal emotions as conveyed by leaderfollower relationship. From a relational signalling perspective to trust building, it implies that mutual respect, loyalty, empathy can be important signals for parties to withheld distrust and open up to socialisation with an attitude to another party. However, positive emotions as an antecedent of organisational trust should be viewed in parallel with organisational practices of monitoring and accountability as organisations in post-soviet context have a risk to turn leadership relationships to nepotistic and favouritism-based ones. These act detrimentally to organisations, undermining its capacity to compete.

Consequently, our study has practical implications for private organisation management and, in particular, leadership development. Training "soft skills" of company managers such as empathy, giving support and staying fair are important to succeed in teamwork and knowledge-based products where organisational trust is essential. Public sector organisations developing organisational trust in a low-trust societal context should consider training employees about importance of ethical values to their organisation, maintaining justice and providing resources. Otherwise, they may risk calling out a sceptical and even cynical reaction to attempts to build ethical culture of organisation and organisational trust. These organisations should consider developing rational rather than emotional aspects as relational signals to the parties in a trust relationship.

Our study bears some limitations. The sample of private organisations was quite heterogeneous, therefore, data from a homogeneous sample would allow to use standardized statistical analysis methods and formulate much more generalizable conclusions. Definitely, the findings obtained from one organisation in public sector are not generalizable to all public sector organisations in Lithuania. Therefore, increasing the sample and testing the relationships in the socio-cultural contexts that are characterised by high trust and less hierarchical and formalised relationships in public sector could enrich these findings.

\section{Acknowledgement}

The funding for this research was received from the European Social Fund under the Global Grant measure, project No. VP1-3.1-ŠMM-07-K-03-042.

\section{References}

Anand, S., Hu, J., Liden, R. C. and Vidyarthi, P. R. (2011), Leader-member exchange: Recent research findings and prospects for the future, In: The Sage Handbook of Leadership, ed. Bryman, A. et al., London: Sage Publications, pp. 311-325.

Andrews, M. C., Baker, T. and Hunt, T. G. (2011), Values and person-organization fit. Does moral intensity strengthen outcomes? Leadership and Organization Development Journal, Vol. 32, No. 10, pp. 5-19.

Barney, J. B. and Hansen, M. H. (1994), Trustworthiness as a Source of Competitive Advantage, Strategic Management Journal, Vol. 15, pp. 175-190.

Blau, P. M. (1964), Exchange and Power in Social Life, New York, NY: John Wiley.

Brien, A. (1998), Professional ethics and the culture of trust, Journal of Business Ethics, Vol. 17, Iss. 4, pp. 391-409. 
Chatman, J. (1989), Improving interactional organisational research: A model of personorganization fit, Academy of Management Review, Vol. 14, No. 3, pp. 333-349.

Chung, Y. and Jackson, S. E. (2011), Co-worker trust and knowledge creation: A multilevel analysis, Journal of Trust Research, Vol. 1, Iss. 1, pp. 65-83.

Ciulla, J. B. and Forsyth, D. R. (2011), Leadership ethics, In: The Sage Handbook of Leadership, ed. Bryman, A. et al., London: Sage Publications, pp. 229-241.

Colquitt, J. A., Lepine, J.A., Zapata, C. P. and, Wild, R. E. (2011), Trust in typical and highreliability contexts: Building and reacting to trust among firefighters, Academy of Management Journal, Vol. 54, No. 5, pp. 999-1015.

Connell, J., Ferres, N. and Travaglione, T. (2003), Engendering trust in manager-subordinate relationships. Predictors and outcomes, Personnel Review, Vol. 32, Iss. 5, pp. 569-587.

Cropanzano, R. and Stein, J. H. (2009), Organisational justice and behavioural ethics: promises and prospects, Business Ethics Quarterly, Vol. 19, Iss. 2, pp. 193-233.

Dansereau, F., Graen, G. and Haga, WJ. (1975), A vertical dyad linkage approach to leadership within formal organisations, Organisational Behaviour and Human Performance, Vol. 13, Iss. 1, pp. 46-78.

Das, T. K. and Teng, B-S. (1998), Between trust and control: developing confidence in partner cooperation alliances, Academy of Management Review, Vol. 23, No. 3, pp. 491512.

Doney, P. M., Cannon, J. P. and Mullen, M. R. (1998), Understanding the influence of national culture on the development of trust, Academy of Management Review, Vol. 23, No. 3, pp. 601-620.

Donoho, C., Heinze, T. and Kondo, C. (2012), Gender differences in personal selling ethics evaluations: Do they exist and what does their existence mean for teaching sales ethics? Journal of Marketing Education, Vol. 34, No. 1, pp. 55-66.

Ees, H. and Bachmann, R. (2006), Transition economies and trust building: a network perspective on EU enlargement, Cambridge Journal of Economics, Vol. 30, pp. 923939.

Ellemers, N., Sleebos, E., Stam, D. and de Gilder, D. (2013), Feeling included and valued: How perceived respect affects positive team identity and willingness to invest in the team, British Journal of Management, Vol. 24, Iss. 1, pp. 21-37.

Ellonen, R., Blomqvist, K. and Puumalainen, K. (2008), The role of trust in organisational innovativeness, European Journal of Innovation, Vol. 11, Iss. 2, pp. 160-181.

Fukuyama, F. (1995), Trust, New York, NY: Simon and Schuster.

Graen, G. B. and Uhl-Bien, M. (1995), Relationship-based approach to leadership: Development of leader-member exchange (LMX) theory of leadership over 25 years: Applying a multi-level multi-domain perspective, Leadership Quarterly, Vol. 6, Iss. 2, pp. 219-247.

Granovetter, M. S. (1973), The strength of weak ties, The American Journal of Sociology, Vol. 78, Iss. 6, pp. 1360-1380.

Grover, S. L. (2010), Lying to bosses, subordinates, peers and the outside world: motivations and consequences, In: Insidious work behaviour, ed. J. Greenberg, New York, Hove: Routledge, pp. 207-235.

Gulati, R. and Sytch, M. (2008), Does familiarity breed trust? Revisiting the antecedents of trust, Managerial Decision Economics, Vol. 29, pp. 165-190.

Hernandez, M., Long, C. P. and Sitkin, S. B. (2014), Cultivating follower trust: Are all leader behaviors equally influential? Organisation Studies, Vol. 35, pp. 1867-1892.

Hogan, R. and Kaiser, R. B. (2005), What we know about leadership, Review of General Psychology, Vol. 9, Iss.2, pp. 169-180.

Huhtala, M., Feldt, T., Hyvönen, K. and Mauno, S. (2013), Ethical organizational culture as a 
context for managers' personal work goals, Journal of Business Ethics, Vol. 114, Iss. 2, pp. $265-282$.

Ivanauskas, V. (2006), Sovietinių biurokratų darbo etika, neformalios rutinos ir planavimo sistemos trūkumai (Lietuvos atvejis) [Work ethics of soviet bureaucrats, informal routines and shortages of the planning system: the case of Soviet Lithuania], Filosofija. Sociologija, No. 4, pp. 1-12.

Jones, G. R. and George, J. F. (1998), The experience and evolution of trust: Implications for cooperation and teamwork, Academy of Management Review, Vol. 23, No.3, pp. 531546.

Kaptein, M. (2008), Developing and testing a measure for the ethical culture of organisations: The corporate ethics virtue model, Journal of Organisational Behaviour, Vol. 29, pp. 923-947.

Kaptein, M. and Schwartz, M. S. (2008), The effectiveness of business codes: A critical examination of existing studies and the development of an integrated research mode, Journal of Business Ethics, Vol. 77, Iss. 2, pp. 111-127.

Lämsä, A.-M. and Pučètaitè, R. (2006), Development of organisational trust among employees from a contextual perspective, Business Ethics: A European Review, Vol. 15, Iss. 2, pp. 130-141.

Ledeneva, A. (2008), "Blat" and "Guanxi": Informal Practices in Russia and China, Comparative Studies in Society and History, Vol. 50, Iss. 1, pp. 118-144.

Lerner, M. J. (2003), The justice motive: Where social psychologists found it, how they lost it, and why they may not find it again, Personality and Social Psychology Review, Vol. 7, No. 4, pp. 388-399.

Lewicki, R. J. and Bunker, B. B. (1996), Developing and maintaining trust in work relationships, In: Trust in Organisations, ed. Kramer, R. M. and Tyler, T. R., Thousand Oaks: Sage, pp. 114-139.

Lewicki, R. J., McAllister, D. J. and Bies, R. J. (1998), Trust and distrust: new relationships and realities, Academy of Management Review, Vol. 23, No. 3, pp. 438-458.

Lewis, J. D. and Weigert, A. (1985), Trust as a social reality, Social Forces, Vol. 63, No. 4, pp. 967-985.

Li, P. P. (2012), When trust matters the most: The imperatives for contextualising trust research, Journal of Trust Research, Vol. 2, Iss. 2, pp. 101-106.

Lindenberg, S. (1998), Solidarity: Its microfoundations and macrodependence. A framing approach, In: The Problem of Solidarity, Theories and Models, ed. Doreian, P. and Fararo, T., Amsterdam: Gordon and Breach, pp. 61-112.

Mayer, R. C. and Gavin, M. B. (2005), Trust in management and performance: Who minds the shop while employees watch the boss? Academy of Management Journal, Vol. 48, No. 5, pp. 874-888.

Mayer, R. C., Davis, J. H. and Schoorman, F. D. (1995), An integrative model of organizational trust, Academy of Management Review, Vol. 20, No. 3, pp. 709-734.

McAllister, D. J. (1995), Affect- and cognition-based trust as foundations for interpersonal cooperation in organisations, Academy of Management Journal, Vol. 38, No. 1, pp. 2459.

McAllister, D. J., Lewicki, R. J. and Chaturvedi, S. (2006), Trust in developing relationships: From theory to measurement, Academy of Management Annual Meeting Proceedings, pp. G1-G6.

Mühlau, P. and Lindenberg, S. (2003), Efficiency wages: Signals or incentives? An empirical study of the relationship between wage and commitment, Journal of Management and Governance, Vol. 7, Iss. 4, pp. 385-400. 
Nie, D. and Lämsä, A.-M. (2015), The leader-member exchange theory in the Chinese context and the ethical challenge of guanxi, Journal of Business Ethics, Vol. 128, Iss. 4, pp. 851-861.

Perry, R. W. (2004), The Relationship of affective organisational commitment with supervisory trust, Review of Public Personnel Administration, Vol. 24, No. 2, pp. 133149.

Pučètaitè, R., Lämsä A.-M., Novelskaitè, A. (2010a), Building organisational trust in a lowtrust societal context, Baltic Journal of Management, Vol. 5, Iss. 2, pp. 197-217.

Pučètaitè, R., Lämsä, A.-M., Novelskaite, A. (2010b), Organisations which have the strongest potential for high-level organisational trust in a low-trust societal context, Transformations in Business and Economics, Vol. 9, Iss. 2B, pp. 318-334.

Pučètaitè, R. and Lämsä, A.-M. (2008a), Developing organisational trust through advancement of employees' work ethics in a post-socialist context, Journal of Business Ethics, Vol. 82, Iss. 2, pp. 325-337.

Pučètaitè, R. and Lämsä A-M. (2008b), Advancing organisational trust in a post-socialist context: role of ethics management tools, Ekonomika ir vadyba - 2008, Kaunas: KTU, pp. 381-388.

Pučètaitè, R. and Novelskaitè, A. (2014), The effect of leader-member exchange on organizational innovativeness: findings from a Lithuanian public sector organization, Journal of International Scientific Publications: Economy and Business, Vol. 8, pp. 159-171.

Putnam, R. (1993), Making democracy work: Civic traditions in modern Italy, Princeton, NJ: Princeton University Press.

Rees, C. J. and Miazhevich, G. (2008), Socio-cultural change and business ethics in postSoviet countries: The cases of Belarus and Estonia, Journal of Business Ethics, Vol. 86, Iss. 1, pp. 51-63.

Rehn, A. and Taalas, S. (2004), "Znakomstva i svyazi” (Acquaintances and connections) Blat, the Soviet Union, and mundane entrepreneurship, Entrepreneurship and Regional Development, Vol. 16, Iss. 3, pp. 235-250.

Ristig, K. (2009), The impact of perceived organisational support and trustworthiness on trust, Managment Research News, Vol. 32, Iss. 7, pp. 659-669.

Ruiz-Palomino, P., Martinez-Canas, R. and Fontrodona, J. (2013), Ethical culture and employee outcomes: The mediating role of person-organization fit, Journal of Business Ethics, Vol. 116, Iss. 1, pp. 173-188.

Ryan, L. V. (2006), Current ethical issues in Polish HRM, Journal of Business Ethics, Vol. 66, pp. 273-290.

Six, F. E. (2007), Building interpersonal trust within organisations: a relational signalling perspective, Journal of Management and Governance, Vol. 11, Iss. 3, pp. 285-309.

Six, F. E. and Sorge, A. (2008), Creating a high-trust organization: An exploration into organizational policies that stimulate interpersonal trust building, Journal of Management Studies, Vol. 45, Iss. 5, pp. 857-884.

Solomon, R. C. (2004), Aristotle, ethics and business organizations, Organization Studies, Vol. 25, No. 6, pp. 1021-1043.

Solomon, R. C. and Flores, F. (2001), Building trust: In business, politics, relationships, and life, Oxford: Oxford University Press.

Sztompka, P. (1999), Trust: A sociological theory, Cambridge: Cambridge University Press.

Tan, H. H. and Lim, A. K. H. (2009), Trust in coworkers and trust in organisations, The Journal of Psychology: Interdisciplinary and Applied, Vol. 143, No. 1, pp. 45-66. 
Thomson, A. M., Perry, J. L. Miller, T. K. (2009), Conceptualizing and measuring collaboration, Journal of Public Administration Research and Theory, Vol. 19, Iss. 1, pp. 23-56.

Tschannen-Moran, M. (2001), Collaboration and the need for trust, Journal of Educational Administration, Vol. 39, No. 4, pp. 308-331.

Tyler, T. R. and Kramer, R. M. (1996), Whither trust, In: Trust in Organisations, ed. Kramer, R. M. and Tyler, T. R., Thousand Oaks: Sage, pp. 1-15.

Uhl-Bien, M. (2006), Relational leadership theory: Exploring the social processes of leadership and organising, The Leadership Quarterly, Vol. 17, No. 6, pp. 654-676.

Ungvari-Zrinyi, I. (2001), Moralinès kultūros tendencijos postkomunistinèse visuomenèse [Moral culture in post-communist countries], In: Dalykinė etika [Business ethics], ed. Vasiljevienè, N., Kaunas: Vilnius University Press, pp. 229-247.

Uslaner, E. M. (2002), The moral foundations of trust, Cambridge: Cambridge University Press.

Vasiljevienè, N. (2000), Verslo etika ir elgesio kodeksai [Business ethics and codes of conduct], Kaunas: VU KHF.

Vasiljevienè, N. (2004), Etikos infrastruktūros diegimas sveikatos priežiūros organizacijose [Implementation of ethics infrastructure in health-care organisations], Vilnius: VU.

Vasiljevienè, N. and Freitakienè, R. (2002), Are we ready to accept European standards? In: Business Ethics: From Theory to Practice, ed. Vasiljevienè, N. and Jeurissen, R. J. M., Vilnius: Vilnius University, pp. 172-195.

Vogt, W. P. (2005), Dictionary of statistics and methodology. A nontechnical guide for the social sciences, 3rd edn., Thousand Oaks, London, New Delhi: Sage Publications.

Whitener, E. M., Brodt, S. E., Korsgaard, M. A. and Werner, J. M. (1998), Managers as initiators of trust: an exchange relationship framework for understanding managerial trustworthy behaviours, Academy of Management Review, Vol. 23, No. 3, pp. 513-530.

Wicks, A. C. and Berman, S. L. (2004), The effects of context on trust in firm-stakeholder relationships: The institutional environment, trust creation, and firm performance, Business Ethics Quarterly, Vol. 14, No. 1, pp. 141-160.

Wicks, A., Berman, S. and Jones, T. (1999), The structure of optimal trust: Moral and strategic implications, Academy of Management Review, Vol. 24, No. 1, pp. 99-116.

Williams, M. (2001), In whom we trust: group membership as an affective context for trust development, Academy of Management Review, Vol. 26, No. 3, pp. 377-396.

Young, L. and Daniel, K. (2003), Affectual trust in the workplace, International Journal of Human Resource Management, Vol. 14, Iss. 1, pp. 139-155.

Zanini, M. T. (2007), Trust within organisations of New Economy: A cross-industrial Study, Wiesbaden, Deutscher Universitaets-Verlag.

Žiliukaitè, R., Ramonaitè, A., Nevinskaitè, L., Beresnevičiūtè, V. and Vinogradnaite, I. (2006), Neatrasta galia: Lietuvos pilietinès visuomenès žemèlapis [Undiscovered power: Map of the civil society in Lithuania], Vilnius: Versus Aureus. 


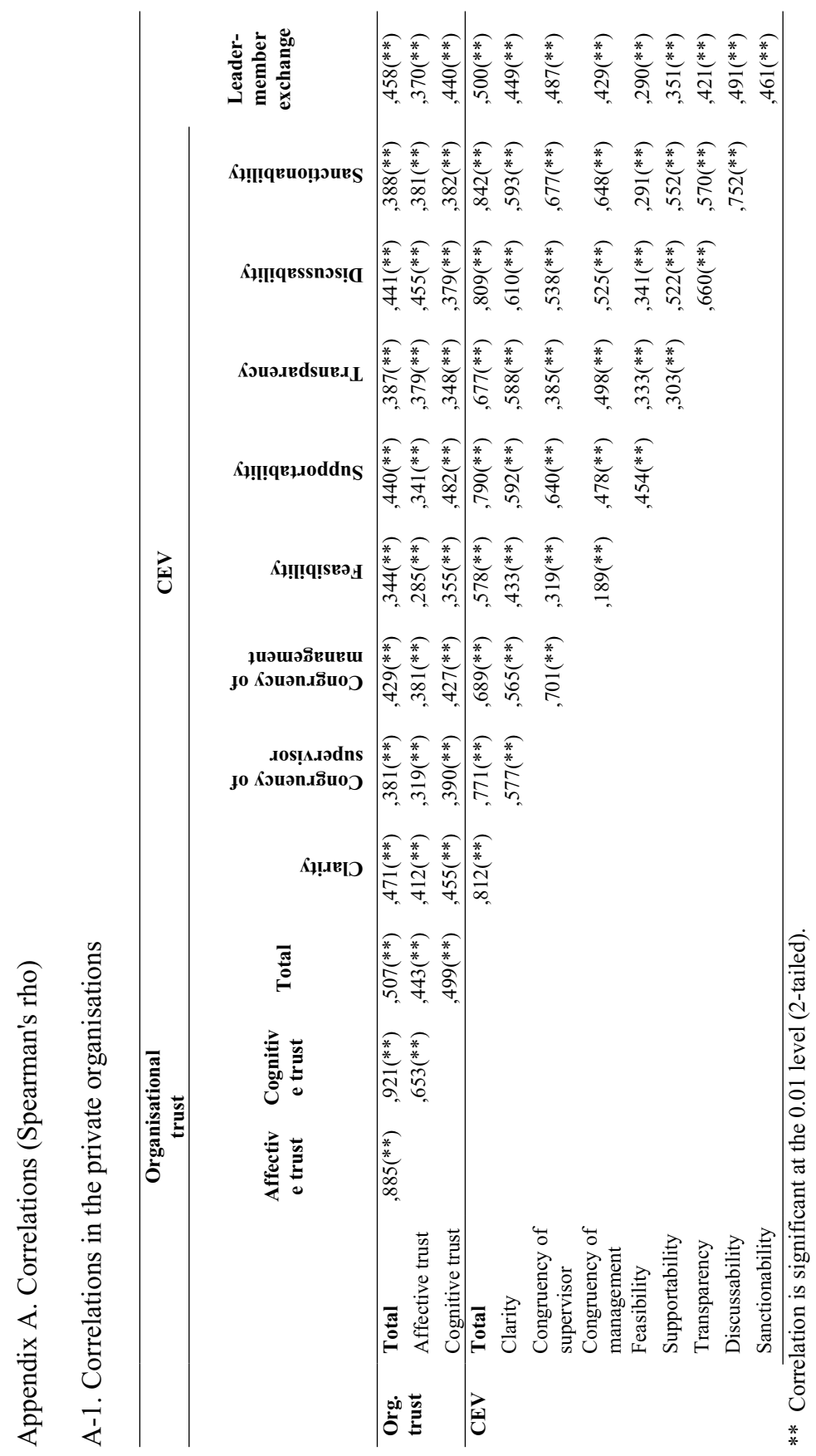




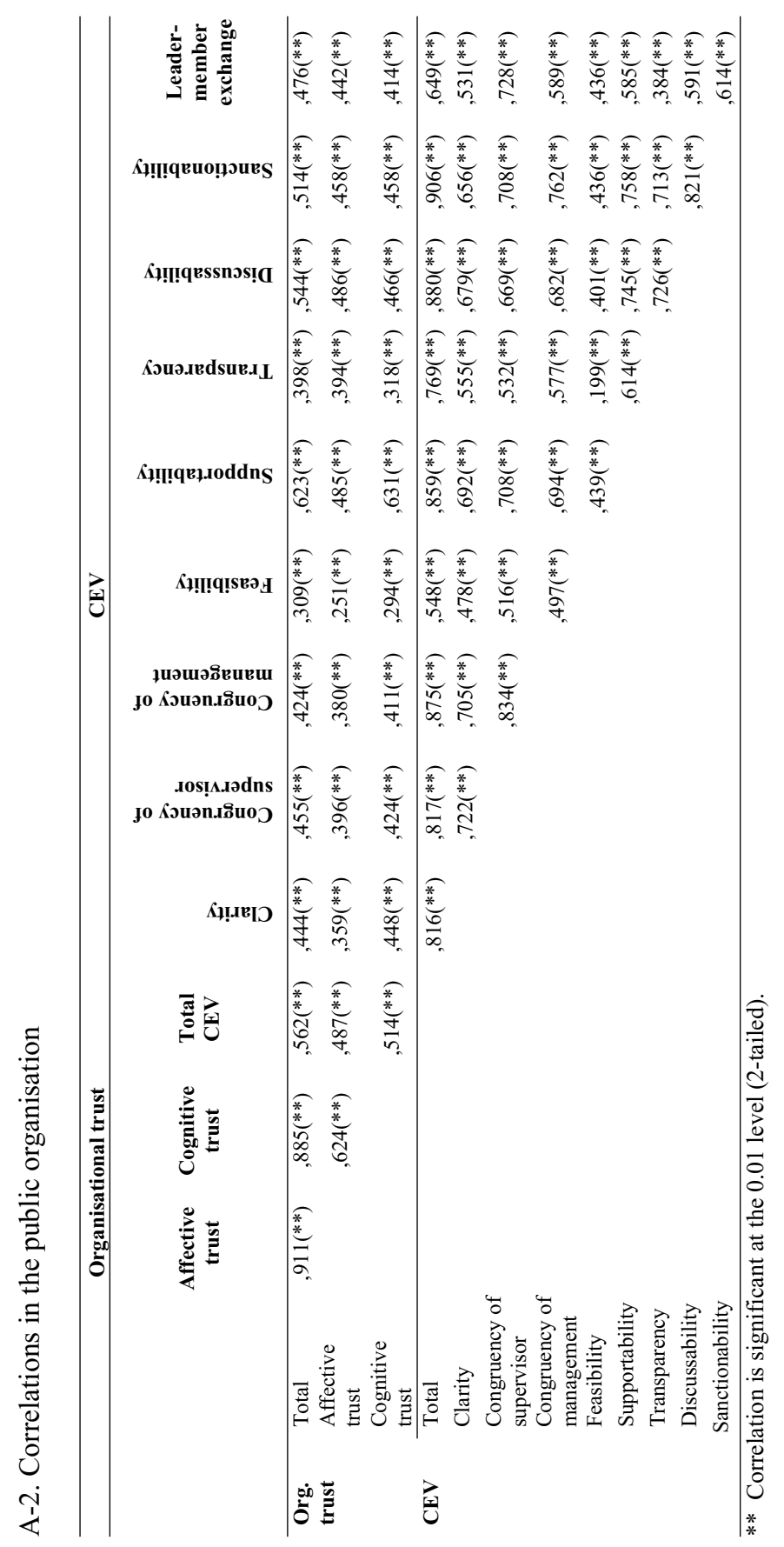




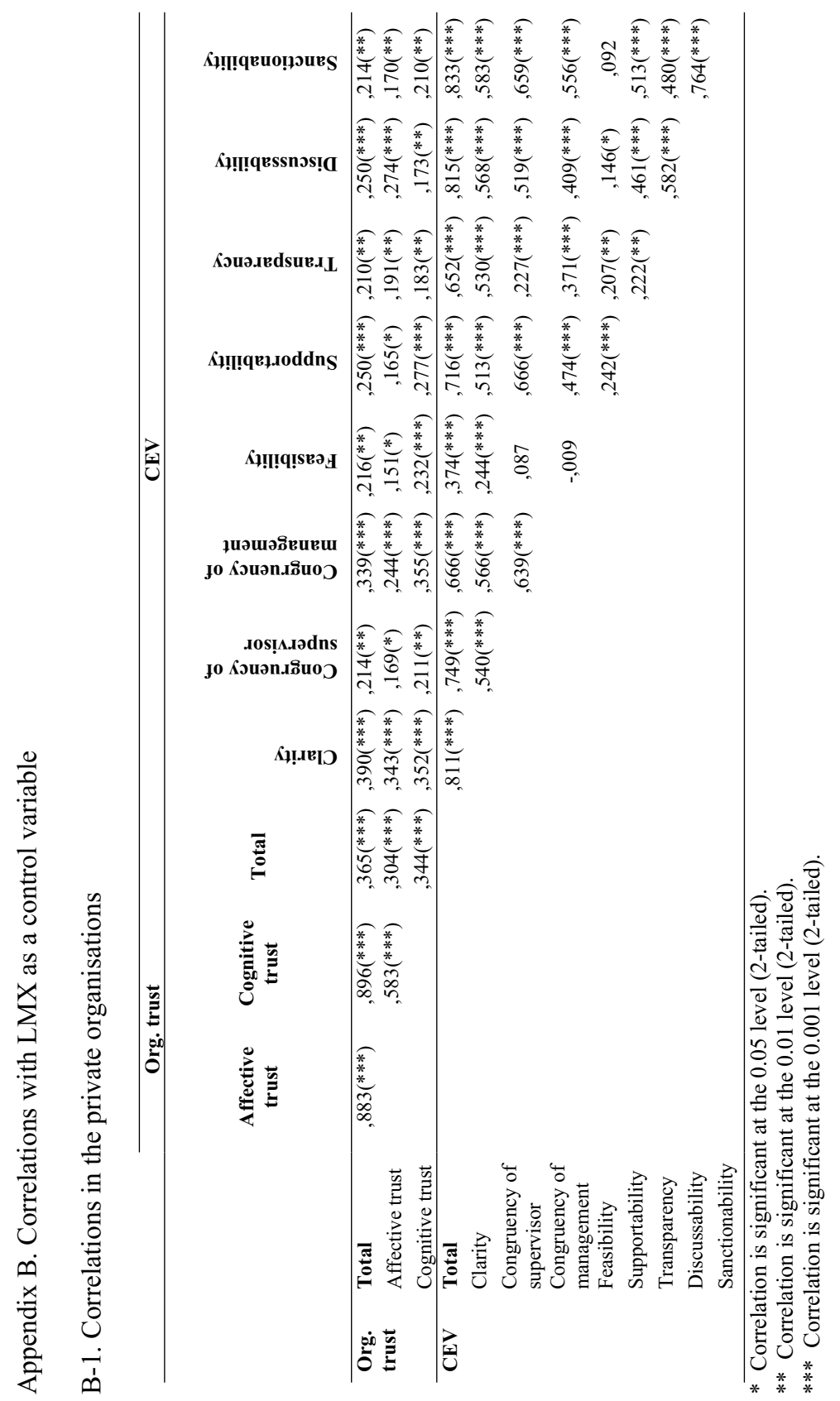




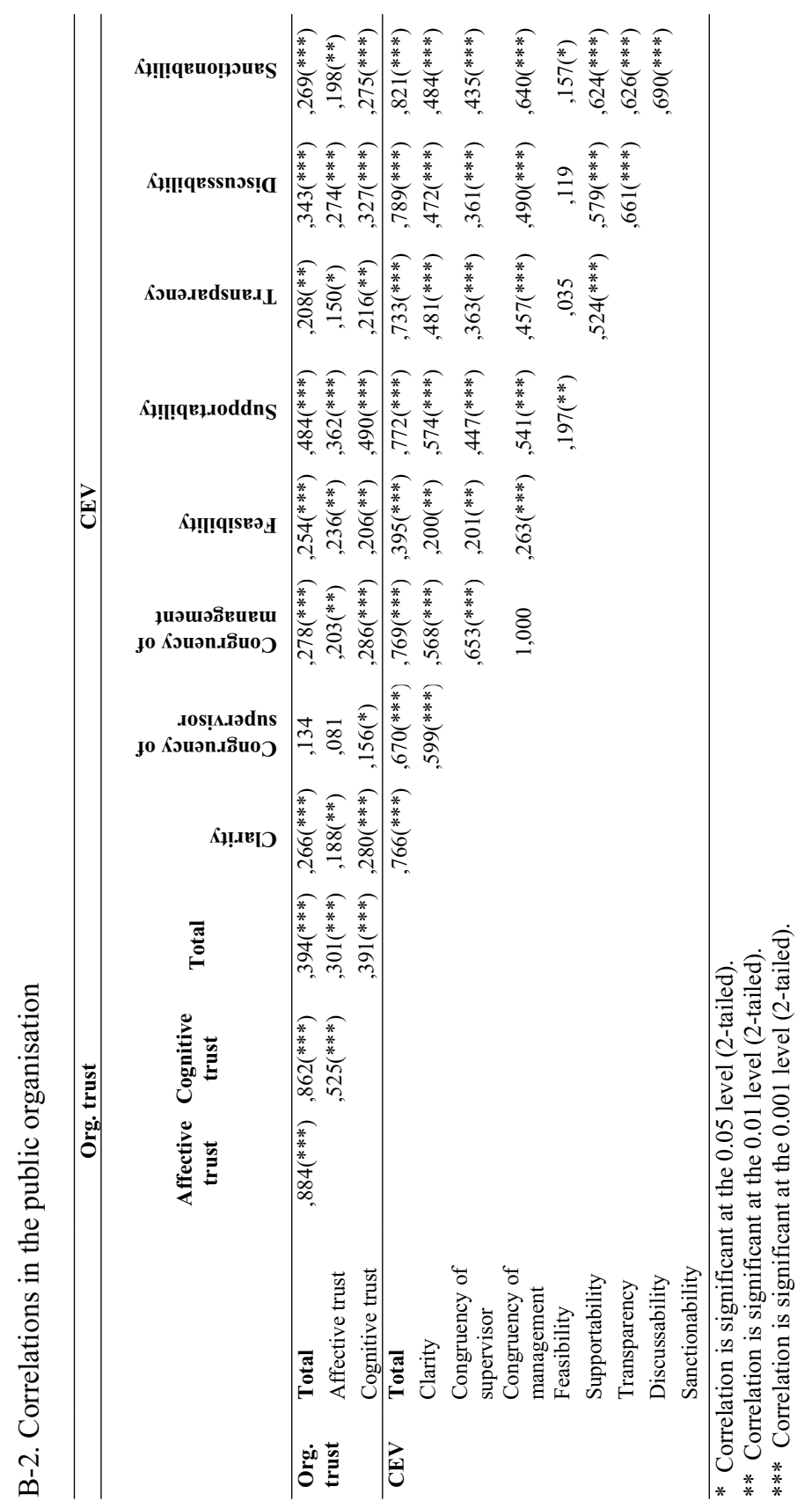

